Discussion Paper No. 14-011

How Important is

Industry-Specific Managerial Experience for Innovative Firm Performance?

Benjamin Balsmeier and Dirk Czarnitzki

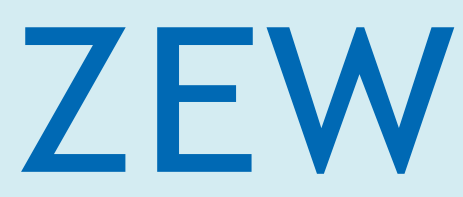

Zentrum für Europäische Wirtschaftsforschung $\mathrm{GmbH}$

Centre for European

Economic Research 
Discussion Paper No. 14-011

\title{
How Important is \\ Industry-Specific Managerial Experience for Innovative Firm Performance?
}

\author{
Benjamin Balsmeier and Dirk Czarnitzki
}

Download this ZEW Discussion Paper from our ftp server:

http://ftp.zew.de/pub/zew-docs/dp/dp14011.pdf

Die Discussion Papers dienen einer möglichst schnellen Verbreitung von neueren Forschungsarbeiten des ZEW. Die Beiträge liegen in alleiniger Verantwortung der Autoren und stellen nicht notwendigerweise die Meinung des ZEW dar.

Discussion Papers are intended to make results of ZEW research promptly available to other economists in order to encourage discussion and suggestions for revisions. The authors are solely responsible for the contents which do not necessarily represent the opinion of the ZEW. 


\section{Non-technical Summary}

According to many studies it is a commonly held view among economists that the level of countries' institutional development is positively associated with economic growth. Among other factors, this interrelation might be explained by higher or more advanced innovative activities of firms operating in countries with well-developed institutional environments. It is thus of great interest to understand how differences in institutional environments moderate firms' decisions to innovate and the success of these activities.

The present study focuses on industry-specific experience of the top manager as a largely neglected but important firm attribute with respect to innovation activities. As experienced managers are likely to have better insights into future business opportunities, threats, niche markets, products, technologies and market development, managerial experience is generally expected to be positively related to innovative activity and its performance. We argue that managerial experience is especially important in environments with lower institutional developments which are presumably less conducive to innovation activities.

The empirical analysis tests this presumption based on the 2008-2009 Business Environment and Enterprise Performance Survey (BEEPS) which comprises firm-level data from 27 Central and Eastern European countries. Regression analyses show that managerial experience enhances both the propensity to innovate and the innovative firm performance, as measured by the share of sales accounted for by new products. Further empirical investigations show that having an experienced manager is especially beneficial for small firms operating outside the EU and in institutionally less developed regions, respectively. These findings support the perception that managerial experience is an important factor explaining firms' innovation activities as it helps to identify new business opportunities and it partly substitutes for institutional obstacles on the road to commercialization of new products. 


\section{Das Wichtigste in Kürze (Summary in German)}

Zahlreiche Studien belegen einen positiven Zusammenhang zwischen den institutionellen Rahmenbedingungen eines Landes und dem Wachstum der Volkswirtschaft. Da dieser Zusammenhang unter anderem auf stärkere und fortschrittlichere Innovationstätigkeit von Unternehmen zurückgeführt werden kann, ist es von großem Interesse, den Zusammenhang zwischen institutionellen Rahmenbedingungen und der unternehmerischen Innovationstätigkeit besser zu verstehen.

Die vorliegende Studie konzentriert sich auf die oft vernachlässigte aber bedeutende branchenspezifische Erfahrung des Topmanagers eines Unternehmens. Da Manager mit zunehmender Erfahrung zukünftige Geschäftsfelder, Technologieentwicklungen oder Marktbedrohungen besser erkennen können, kann generell ein positiver Zusammenhang zwischen der Erfahrung des Topmanagers und dem Erfolg vonInnovationstätigkeiten angenommen werden. Ferner legen wir dar, dass branchenspezifische Expertise der Unternehmensleitung gerade in Ländern mit weniger entwickelten Institutionen sehr bedeutend für erfolgreiche Innovationstätigkeit ist.

Die empirische Analyse testet diese Vermutung basierend auf dem „Business Environment and Enterprise Performance Survey" aus den Jahren 2008 und 2009. Die Datenbank enthält Unternehmensdaten aus 27 zentral- und osteuropäischen Ländern. Regressionsanalysen zeigen, dass die Erfahrung des Topmanagers einen positiven Einfluss sowohl auf die Innovationswahrscheinlichkeit als auch auf den Innovationserfolg hat. Weitere Analysen zeigen, dass dieser positive Einfluss der Managererfahrung besonders für kleine Unternehmen gilt, die ihren Unternehmenssitz außerhalb der EU oder in generell weniger entwickelten Ländern haben. Die Industrieerfahrung des Topmanagers ist mithin eine wichtige Determinante unternehmerischer Innovationstätigkeit, die zudem als Substitut für schwache institutionelle Rahmenbedingungen dienen kann. 


\title{
How Important is Industry-Specific Managerial Experience for Innovative Firm Performance?
}

\author{
Benjamin Balsmeier ${ }^{\mathrm{a}, \mathrm{b}}$ and Dirk Czarnitzki ${ }^{\mathrm{a}, \mathrm{c}, \mathrm{d}}$ \\ a) KU Leuven, Dept. of Managerial Economics, Strategy and Innovation, Leuven, Belgium \\ b) University of Münster, Institute for Organizational Economics, Münster, Germany \\ c) Centre for R\&D Monitoring (ECOOM), Leuven, Belgium \\ d) Centre for European Economic Research (ZEW), Mannheim, Germany
}

January 2014

\begin{abstract}
This study examines how industry-specific managerial experience affects firms' innovation performance in the context of different institutional environments. Based on firm-level data from 27 Central and Eastern European countries we identify a robust positive relationship between industry-specific experience of the top-manager and the decision to innovate as well as the share of new product-related sales. These effects are particularly pronounced for small firms operating outside the European Union or, more generally, in institutionally less developed countries. The results suggest that managerial experience affects firm innovations largely indirectly, for example, by reducing uncertainty about future returns on innovations or by providing knowledge about how to cope with institutional shortfalls potentially hampering the commercial success of new products.
\end{abstract}

JEL-Classification: G38, L25, O32, P26

Keywords: $\quad$ Corporate Governance, Innovation, Managerial Experience

\section{Contact details:}

\section{Benjamin Balsmeier}

KU Leuven, Department of Managerial Economics Strategy and Innovation, Naamsestraat 69, 3000 Leuven, Belgium phone: +32 16326 682, e-mail: Benjamin.Balsmeier@kuleuven.be

Dirk Czarnitzki

KU Leuven, Department of Managerial Economics Strategy and Innovation, Naamsestraat 69, 3000 Leuven, Belgium phone: +32 16326 906, e-mail: Dirk.Czarnitzki@kuleuven.be

* Both authors gratefully acknowledge financial support from the Flemish Science Foundation (grant G.0282.10). We also thank Alberto Galasso and the participants of the EARIE 2011, the IIOC 2012 and the MSI faculty lunch seminar at KU Leuven for many valuable comments. 


\section{Introduction}

Several studies support the perception of a strong positive relationship between institutional development and economic growth at the country level (e.g. Acemoglu et al., 2002, 2005, Barro, 1990, Beck et al., 2005, Claessens \& Laeven, 2003, Djankov et al., 2003, Johnson et al., 2002, La Porta et al., 1998, 2002). This interrelation can be explained, at least partly, by higher or more advanced innovative activities of firms in countries with well-developed institutional environments (Romer, 1990, Varsakelis, 2001, Lin et al. 2010). Encouraging firms to develop new products is thus recognized as one of the most important mechanisms for improving long-run economic performance by scholars and policy makers as well as managers. This view is also broadly supported by the existing literature which provides robust evidence that innovations have a positive impact on firm productivity (see e.g. Stiglitz, 1969, Griliches, 1980, Schankerman, 1981, Griliches \& Mairesse, 1984, 1990, and Hall \& Mairesse, 1995, for early, influential studies, or Hall et al., 2010, for a recent survey). As corporate innovative activities are one of the most important drivers of long-term firm performance it is of great interest to understand how differences in institutional environments moderate the decision to innovate and the success of these activities at the firm level.

Apart from determinants like firm size, market structure, industry (e.g. Scherer, 1984, Acs \& Audretsch, 1987, 1988, Bertschek \& Entorf, 1996), spillovers (e.g. Acs et al., 1994), strategy (e.g. Baysinger \& Hoskisson, 1989) and ownership structure (e.g. Baysinger et al., 1991, Czarnitzki \& Kraft, 2009), recently the top-manager of a firm became another focus in research on innovative firm performance (e.g. Barker \& Mueller, 2002, Bertrand \& Schoar, 2003, Mackey, 2008, Eggers \& Kaplan, 2009 or Galasso \& Simcoe, 2011). A firm's top management might be an especially crucial factor to be considered when a firm operates in less developed institutional environments, as it is believed, for instance, that managerial 
knowledge about institutions reduces uncertainty and makes expectations about business opportunities more accurate and realistic (Penrose 1959, Johanson \& Wiedersheim-Paul 1975, Chetty et al. 2006). Managerial knowledge about how to deal with institutional shortfalls and other obstacles on the way to the successful commercialization of new inventions naturally increases with past experiences.

The presumption that managerial experience affects firm behavior has been noted by several scholars and empirically confirmed for variables other than innovation (e.g. Kor 2003, Bach \& Smith, 2007, Holmes \& Schmitz, 1996, Eisenhardt and Schoonhoven, 1990, Keeley and Roure, 1990). Most empirical papers dealing with managerial experience focus on startups and examine the impact of the founders experience on firm performance and survival rates, typically showing positive effects (e.g. Pennings et al., 1998, Klepper, 2001, Agarwal et al., 2004, Filatotchev et al., 2009). Another related strand of the literature recognizes a positive link between experience-based human capital of board members and the growth of publicly listed firms (e.g. Kor \& Sundaramurthy, 2009, Kor \& Misangyi, 2008, Kor 2003). The link between top-manager experience and innovative firm activities is however only rarely analyzed (see Weterings \& Koster, 2007, for an exception) and, if so, only for one specific industry and not in the context of different institutional environments.

As experienced managers are likely to have better insights into future business opportunities, threats, niche markets (Shane, 2000), products, technologies or market development (Helfat \& Liebermann, 2002), managerial experience is expected to be positively related to innovative activity and its performance. In this study we argue that the positive effect of managerial experience on innovative firm activities is presumably more pronounced in countries with less developed institutions as firms operating in such environments have to rely relatively more on informal agreements, personal reputation and knowledge on how to deal with external institutional shortfalls. 
Previous efforts to disentangle these effects have been limited by the availability of comparable firm-level data on managerial experience as well as innovative firm activities in a setting of different institutional environments. This study circumvents these former obstacles by using the 2008-2009 Business Environment and Enterprise Performance Survey (BEEPS) which comprises comparable firm-level data from 27 Central and Eastern European countries, across which the state of the institutional environment varies considerably.

The present study aims at adding new insights to the emerging debate about how much top-managers matter for organizational outcomes, emphasizing industry-specific experience of the top executive as a largely neglected but important attribute. By exploring the moderating role of institutional environments on the link between top-manager experience and a firm's decision to innovate and its success, this study also contributes to the general debate on how the institutional environment shapes individual firm behavior (e.g. North, 1990, Grossmann \& Helpman, 1991, Helpman, 1993, Glass \& Saggi, 2002, Branstetter et al., 2006, Filatotchev et al., 2012, Hoskisson et al., 2000, Hoskisson et al., 2012, Meyer and Peng, 2005, Peng, 2003, Wright et al., 2005).

The empirical analysis reveals that managerial experience enhances both the decision to innovate and the innovative firm performance, as measured by the share of sales accounted for by new products. Further empirical investigations show that having an experienced manager is especially beneficial for small firms operating outside the EU and in institutionally less developed regions, respectively. We interpret these findings as support for the perception that managerial experience is an important factor explaining firms' innovation activities as it helps to identify new business opportunities and substitutes for institutional obstacles on the road to commercialization of new products.

The remainder of the paper is organized as follows. Section 2 reviews the underlying theoretical background and existing findings on the interrelation between managerial 
experience, institutional development and innovation. Section 3 describes the data and methods used. In Section 4, the empirical results are presented and discussed. Finally, section 5 concludes.

\section{Managerial experience, innovation and institutional development}

\subsection{Managerial experience and innovation}

Experiences of managers are part of their human capital and comprise technological, commercial, organizational and managerial skills and knowledge that managers accumulate during their careers (Weterings \& Koster, 2007). Such capabilities may serve as an important input factor of a firm. As intellectual assets are not easily imitable by rivals, they presumably result in a competitive advantage of firms possessing them. Knowledge about how to profitably innovate typically requires a good understanding of relevant technologies and evolving markets. As new developments and technologies within an industry often follow a path-dependent pattern, knowledge about past industry conditions enhance managers' capability to understand current and predict future industry dynamics (Arthur, 1994, Kor \& Sundaramurthy, 2009) Hence, industry-specific experience of the top-manager might be crucial for the success of corporate innovative activities. This perception is, among others, supported by Klepper \& Simons (2000) who reveal positive effects of experience in the radio industry for successfully entering the TV receiver market. Furthermore, the literature on startups also suggests that industry-specific experiences are particular valuable to improve the firm performance of newly founded firms (Garvin, 1983, Klepper, 2001, Agarwal et al., 2004, Dahl \& Reichstein, 2007, Filatotchev et al., 2009). Likewise does the industry specific experience of board members, who advise and monitor top executives, help young, listed firms to grow faster (Kor, 2009). 
The managers' capabilities may be utilized through superior exploitation of firms' available resources. This can happen either in creative manner or with respect to efficiency of the innovation process. Experienced managers may have an advantage in anticipating future business opportunities, threats, competitive pressure and changes in technology and customer demand (Boeker 1997; Helfat \& Lieberman, 2002, Kor, 2003, Shane, 2000, Spender, 1989) that helps generating original ideas for new product developments. Relatedly, experienced managers may have advantages in accessing external resources like skilled labor within an industry or suppliers of scarce, highly-specialized or customized goods (Pennings et al., 1998, Sorenson, 2003) which might be a necessary input for successful innovation. Information on such crucial input factors and how to employ those are not necessarily freely available in the market but rather acquired during a career. Long-term industry experience in combination with exemplary conduct will also provide the manager with a well-established network to horizontally or vertically related firms, contributing to the firm's reputation (Certo, 2003, Mizruchi \& Stearns, 1994). This will be conducive to strategic alliances with external partners, suppliers and customers and in turn may enhance innovative firm performance (Stuart and Sorenson 2003).

In the present study we are not primarily interested in a specific channel through which managerial experience influences innovative firm activities but rather in the general effect of industry-specific experience on the decision to innovate and to successfully commercialize new products. We assume that the aforementioned factors contribute positively to the firm's capabilities to innovate and these capabilities are positively associated with increasing industry-specific experience of the top-manager, on average. Even without knowing the exact channel through which managerial experience affects firms' decision making and organizational behavior it seems reasonable to conjecture that top-manager experience generally reduces the risk of failure and uncertainty about future returns to innovative firm 
activities. Both effects should result in higher innovation propensities. ${ }^{1}$ If experienced managers indeed improve access to crucial input factors, provide contacts to customers, suppliers and scarce labor, this should become also observable in more successful commercialization of new products. This leads to our first hypothesis:

H1a: Managerial experience is positively associated with the likelihood of new product introductions.

H1b: Managerial experience is positively associated with the commercial success of new product introductions.

\subsection{Institutional development and innovative firm activity}

When managers make decisions on innovations or related firm activities, they are made against the background of the specific environment a firm is operating in. It is well known that besides firm-specific and industry-specific aspects, corporate strategy is influenced by the institutional environment (see e.g. Grossmann \& Helpman, 1991, Helpman, 1993, Glass \& Saggi, 2002, Branstetter et al., 2006, Filatotchev et al., 2012, Hoskisson et al., 2000, Hoskisson et al., 2012, Meyer and Peng, 2005, Peng, 2003, Wright et al., 2005) or (expectations about) the political and economic stability (see e.g. North, 1990, Barro, 1990, Claessens \& Laeven, 2003).

Institutional factors can have a considerable influence on corporate innovation activity, because many inventions may require a long-lasting development process until fully commercialized. Therefore, well-functioning institutions might be essential for investment decisions of firms. For instance, well-designed property rights and effective contract enforcement are required in order to ensure the successful commercialization of new product or process developments in the post R\&D stage (Lin et al., 2010). As rational agents take

\footnotetext{
${ }^{1}$ See e.g. Czarnitzki and Toole $(2011,2013)$ for empirical studies showing a negative relationship between uncertainty about innovation success and the level of innovation activity at the firm level.
} 
these issues into account when investment decisions are made, the state of institutional development should matter for innovation activities at the firm-level.

When countries lack fundamental market supporting institutions, managers and firms often have to perform basic functions themselves (Khanna \& Palepu, 1997, Peng \& Luo 2000). Generally, the lower the strength of external institutions, the more important becomes the leader of the firm and his or her personal reputation and knowledge about how to cope with all kinds of institutional shortfalls and uncertainty towards the future economic development (Penrose, 1959, Chetty et al., 2006). Hence, it is likely that differences with regard to external institutions also moderate the role of managerial experience in innovative firm activities.

Weak institutional environments are usually associated with rather weak property rights protection, a less developed market system, more governmental slack and problems obtaining capital for corporate investments. Therefore, a successful business strategy in institutionally less developed surroundings has to rely more on trust, personal reputation, established relationships, informal contacts and personal information on whom to contact in certain situations (Peng \& Health 1996, Peng \& Luo, 2000, Li \& Zhang, 2007). For instance, in environments where getting an internet connection, a license for producing and/or selling a new product or importing and exporting certain goods depends on asking or even bribing the right people, personal knowledge about these issues can be crucial for receiving the maximum possible returns to innovative activities. Well established relationships to employees, suppliers and customers, which are built up during a career, may help to overcome uncertainty and costly negotiations due to weak contract enforcement and property rights protection. Furthermore, obtaining capital for corporate investments is particularly difficult in weak or differently speaking less market oriented institutional environments (La Porta et al., 1997, 1998, 1999, 2008). If managerial experience has the expected positive 
effects on doing business, banks and other capital providers may take the experience of the top-manager positively into account when making lending decisions. A manager's experience may stand for a lower likelihood of bankruptcy. Without any industry-specific experience of the top-manager, banks may not be willing to lend money at all. Such an effect would further enhance the positive influence of managerial experience on innovative firm activities, as it is known that financial constraints due to rather high uncertainty about future returns to innovations are one of the main reasons withholding firms from introducing new products.

As all these issues are arguably more pronounced in weaker institutional environments, managerial experience may have a more positive impact on innovative performance in less developed countries. In other words, experience may serve as a substitute for some institutional shortfalls via offering reputation, trustworthiness, personal contacts and knowledge about how to cope with institutional weaknesses. This reasoning leads to our second pair of hypotheses to be tested:

H2a: The positive link between managerial experience and the likelihood to introduce new products is especially pronounced in economies with weak institutional environments.

H2b: The positive link between managerial experience and the commercial success of new product introductions is especially pronounced in economies with weak institutional environments.

The existing literature on managerial experience has so far focused largely on firm foundations and spin-offs, repeatedly finding positive effects. The link between managerial experience and corporate innovative activity is however only rarely analyzed. A further limitation of the existing literature is that it often relies on data from one specific industry in one developed economy. Using firm-level cross-country data from 27 different economies, the present study is, to best of our knowledge, the first one that analyzes top-manager 
experience in such a broad framework. Taking advantage of the fact that the state of institutional development varies widely across our sample, we are able to add new insights to the interrelation between firm-level innovations, corporate governance and external institutional development.

\section{Data, descriptive statistics and methodological remarks}

For our empirical investigation of managerial experience on innovative performance in different institutional surroundings we use the 2008-2009 wave of the Business Environment and Enterprise Performance Survey (BEEPS). ${ }^{2}$ An important feature of the BEEPS data for our study is the fact that it provides comparable information on the years of industry-specific experience of the top-manager for a large set of firms in different countries. By covering 27 countries, and among those recent or former transition economies, the status of institutional development varies exceptionally high across countries. This enables us to disentangle the moderating role of different levels of institutional development on the influence of managerial experience on innovative firm performance.

In particular, we propose to split the sample countries basically into two groups, that is, into countries that have a well-developed institutional environment versus those where economic freedom might still be restricted due to weak institutional environments. First, we suggest that distinguishing between EU member states and other Central and Eastern European countries leads to a meaningful differentiation of countries in the sample. It can be argued that in EU member states the institutional development is relatively high. This view is, for instance, supported by Belke et al. (2009) who report considerable institutional improvements for those nine countries that joined the EU within the last decade.

\footnotetext{
${ }^{2}$ The data is freely available for research purposes at the website of the EBRD "http://www.ebrd.com/pages/research/analysis/surveys/beeps.shtml". Former waves do not include information about managerial experience, so we rely solely on the 2008-2009 wave for our study. See this website also for further detailed information on the construction of the survey.
} 
As an alternative to the EU vs. non-EU country differentiation, we also collected data on the Economic Freedom index developed by 'The Heritage Foundation' in partnership with 'The Wall Street Journal' (hereafter only Heritage Foundation). ${ }^{3}$ The Heritage Foundation measures economic freedom in 184 countries around the world on a scale from 1 to 100 since 1995. A rating of 1 represents the lowest degree and 100 the highest. The index of economic freedom combines 4 sub-categories (each containing 2-3 further sub-indices):

i. The sub-category 'Rule of Law' measures the strength of the property rights and the freedom from corruption.

ii. Ratings of fiscal freedom and governmental spending are combined under the 'Limited Government' category.

iii. 'Regulatory Efficiency' is proxied by indices on business freedom, labor freedom and monetary freedom.

iv. Finally, an 'Open Markets' category supplements the former ones with indices on trade freedom, investment freedom, and financial freedom.

The economic freedom rating, that we use to measure the state of institutional development, is calculated as the average score of the sub-indices. The underlying research and rating process is based on a sophisticated standardized system that involves a crew of analysts, senior-level academic advisers and evaluations from various other institutions, e.g. the World Bank's Economist Intelligence Unit or the U.S. Department of Commerce. ${ }^{4}$ As we expect to find that managerial experience matters most for innovative firm activity when external institutions are rather weak, alternatively to the EU-membership status we consequently identified those firms operating in environments falling under the lowest half of

\footnotetext{
3 We also checked alternative sources, e.g. Freedom House indices from http://www.freedomhouse.org and data from the World Economic Forum's Global Competitiveness Report. Since we found always high correlations between other indices and also between the sub-indices, we only report results based on the economic freedom index that combines all major sub-fields relevant for firms' innovative performance.

4 For a detailed description of the underlying methodology see, for instance, the website http://www.heritage.org/index/book/methodology.
} 
the economic freedom rating. Accordingly one sample part consists of all firms incorporated in countries with rather weak institutional environments (indicated by ' $W I$ '), which are characterized by an economic freedom score below the median value of 59.9, while all other countries fall in the group of rather well developed countries. ${ }^{5}$

Table 1 shows all covered countries, the number of observed companies per country and information on whether the respective country is a member of the EU or has weak external institutions (WI) according to the Heritage Foundation's Economic Freedom Index. The data is a cross-sectional random sample of 11,800 firms from 27 Central and Eastern European countries. ${ }^{6}$ After removing observations with inconsistent answers in the questionnaire or missing values in the variables of interest, the final sample includes 7,806 observations in total. ${ }^{7}$

\footnotetext{
${ }^{5}$ All subsequently presented estimations were also performed with different separating values of 'WI' but showed qualitatively the same results.

${ }^{6}$ The difference of the institutional development of EU-member countries and non-EU-member countries is also supported by significant differences in the indices of the Heritage Foundation measuring economic freedom. The EU member countries have, on average a much higher value of institutional development than the non-EU members. In addition, the institutional development within the EU is also more harmonized than in the other countries as can be seen in the lower standard deviation of the Economic Freedom Index in Table 3.

${ }^{7}$ As the data in the survey is obtained by personal interviews we also checked for difference in our results when less trustable cases are removed as indicated by bad interview/respondent quality. Since we find none, the presented results are based on all available observations. We removed one observation where 777,777 employees in $t$-3 were reported, because this observation is a clear outlier (next smaller firm has 15,000 employees in $t-3$ ) and would, thus, bias the size effect estimation in our regressions. Finally, we checked whether our results are influenced by those few managers who reported more than 50 years of industry-specific experience. As we found no meaningful difference in our estimations, we left them in the sample.
} 
Table 1: Sample overview

\begin{tabular}{|c|c|c|c|c|c|c|c|c|c|}
\hline Country & Freq. & Percent & EU-member & $\begin{array}{c}\text { Weak } \\
\text { institutions }\end{array}$ & Country & Freq. & Percent & EU-member & $\begin{array}{c}\text { Weak } \\
\text { institutions }\end{array}$ \\
\hline Albania & 39 & 0.5 & & & Latvia & 207 & 2.65 & $\mathrm{EU}$ & \\
\hline Armenia & 252 & 3.23 & & & Lithuania & 205 & 2.63 & EU & \\
\hline Azerbaijan & 265 & 3.39 & & WI & Montenegro & 83 & 1.06 & & WI \\
\hline Belarus & 195 & 2.5 & & WI & Poland & 262 & 3.36 & EU & \\
\hline Bosnia & 257 & 3.29 & & WI & Romania & 370 & 4.74 & EU & \\
\hline Bulgaria & 229 & 2.93 & EU & & Russia & 936 & 11.99 & & WI \\
\hline Croatia & 92 & 1.18 & & WI & Serbia & 323 & 4.14 & & WI \\
\hline Czech Republic & 143 & 1.83 & EU & & Slovakia & 159 & 2.04 & EU & \\
\hline Estonia & 222 & 2.84 & EU & & Slovenia & 225 & 2.88 & EU & \\
\hline Fyrom & 241 & 3.09 & & & Tajikistan & 255 & 3.27 & & WI \\
\hline Georgia & 261 & 3.34 & & & Turkey & 776 & 9.94 & & \\
\hline Hungary & 256 & 3.28 & EU & & Ukraine & 612 & 7.84 & & WI \\
\hline Kazakhstan & 399 & 5.11 & & & Uzbekistan & 341 & 4.37 & & WI \\
\hline Kyrgyz & 201 & 2.57 & & & & & & & \\
\hline
\end{tabular}

Total number of observations: 7,806

\section{Variables}

As dependent variables we use one binary variable and one continuous variable that proxy for corporate innovative performance. These are the only innovation variables that can be obtained from the BEEPS for a large sample of firms. The first innovation dummy 'new product/service' indicates whether a firm has introduced new products or services in the last three years. The second variable 'innovation sales' approximates the success of those innovations, as measured by the share of the last fiscal year's annual sales that were achieved with new products and services introduced during the last three years. ${ }^{8}$

Our main explanatory variable 'experience' is the industry-specific experience of the top-manager of each firm, which is calculated as the number of years the top-manager worked in the current industry. In the regression analysis we use the logarithm of experience

\footnotetext{
8 We acknowledge that both innovation measures may not always indicate a positive outcome, because some firms may introduce too many new products to the market or a high proportion of new product related sales might be driven by less successful prior products rather than the success of the newly introduced one. As the BEEPS data is anonymized we are also not able to match other indicators, e.g. patent data, to address unobserved heterogeneity with regard to the radicalness of the indicated innovations. Given the comprehensive evidence on positive effects of innovative firm activities on firm performance on average (see e.g. Stiglitz, 1969, Griliches, 1980, Schankerman, 1981, Griliches \& Mairesse, 1984, 1990, and Hall \& Mairesse, 1995, for early, influential studies, or Hall et al., 2010, for a recent survey) we believe that this should not limit our examination to a large extent.
} 
in order to allow for diminishing marginal returns of experience on corporate innovative activity, incorporating the idea that the most important experiences are made during the first years and the additional gain in knowledge becomes less important over time. We will estimate the effect of managerial experience on innovative activity, measured by 'new product/service' and 'innovation sales', respectively, for (i) all firms in the sample, (ii) separately for firms operating in EU-member states and non-EU-member states (see sample definition in Table 1), and, (iii) in alternative specifications separately for firms operating in rather weak versus strong institutional environments.

To estimate differences in the effects of managerial experience on innovative performance we run regressions of innovation performance on managerial experience where we estimate separate slopes for firms in countries with well-developed institutions versus less developed institutions. This is implemented by estimating a slope for experience*EU and a different slope for experience*(1-EU) in the specifications where we presume that EU members have better developed institutions than the other countries in the sample, on average. We proceed analogously in the regressions where we use the Economic Freedom Index rather than the EU vs. non-EU comparison.

As managerial experience might not be the only variable that affects corporate innovative activity, several control variables are added that could possibly confound the estimated relationship between 'experience' and innovation. Wherever available we took a lagged variable to minimize potential simultaneity issues. ${ }^{9}$

Firms that invest into R\&D will be both more likely to introduce new products and/or services and to be also more successful in commercializing those products. Hence, a binary

\footnotetext{
9 As some variables are only available for the period $t-3$, for consistency reasons we choose to take also with regard to other variables, wherever possible, values from $t-3$.
} 
control variable indicating whether the firm has invested into ' $R \& D$ ' in the last three years is added to the regressions. ${ }^{10}$

With the size of a company, which is measured by the logarithm of employees in period $t-3$, we control for the fact that larger firms might be able to realize economies of scale and scope in their innovation process.

Younger firms might be more innovative than other firms as they have less standardized products and have usually not exploited all resources yet (cf. e.g. Kleinknecht 1996). Therefore, the logarithm of a firm's age in $t-3$ is included as a further explanatory variable in the regression framework.

In addition, we control for human capital intensity by the fraction of employees with a university degree, since a highly skilled workforce can be assumed to facilitate inventions of new products and their successful commercialization.

Access to foreign markets is usually a strong incentive for firms to be innovative, because the reachable markets for new products tend to be larger and firms may learn through exporting. Thus, a dummy indicating whether the firm was exporting in $t-3$ is taken as another explanatory variable into account.

Furthermore, we control for possible differences in innovative activity of state-owned and foreign-owned firms when compared to privately owned, domestic companies. Two dummy variables indicating firms that are state-owned or foreign-owned account for these specific kinds of ownership.

Finally, we use one year dummy (the data is cross-sectional but the interviews were conducted during 2008 and 2009 in different countries), 17 industry dummies and 26 country dummies to control for unobserved heterogeneity over time, and across different industries and countries. Table 2 summarizes all variables used.

\footnotetext{
10 We took a R\&D dummy instead of the amount invested as the latter has unfortunately been missing too frequently in the raw data.
} 
Table 2 - Variable overview

\begin{tabular}{|c|c|c|}
\hline Variable & Description & Source \\
\hline New product/service & $\begin{array}{l}\text { Dummy indicating whether the firm has } \\
\text { introduced a new product or service within } \\
\text { the last three years }\end{array}$ & BEEPS \\
\hline Innovation sales & $\begin{array}{l}\text { Annual percentage of sales accounted for by } \\
\text { new products or services introduced in the } \\
\text { last three years }\end{array}$ & BEEPS \\
\hline $\mathrm{R} \& \mathrm{D}$ & $\begin{array}{l}\text { Dummy indicating whether the firm has } \\
\text { invested in } R \& D \text { in the last three years }\end{array}$ & BEEPS \\
\hline Experience & $\begin{array}{l}\text { Number of years the top-manager of the firm } \\
\text { works in the current industry }\end{array}$ & BEEPS \\
\hline Employees $_{t-3}$ & Employment in physical units in $t-3$ & BEEPS \\
\hline $\operatorname{Age}_{t-3}$ & Age of the firm in years in $t-3$ & BEEPS \\
\hline Human capital & $\begin{array}{l}\text { Percentage of employees with a university } \\
\text { degree }\end{array}$ & BEEPS \\
\hline Export $_{\mathrm{t}-3}$ & $\begin{array}{l}\text { Dummy indicating whether the firm exported } \\
\text { in } t-3\end{array}$ & BEEPS \\
\hline State owned & $\begin{array}{l}\text { Dummy indicating whether the firm is } \\
\text { wholly owned by the government }\end{array}$ & BEEPS \\
\hline Foreign owned & $\begin{array}{l}\text { Dummy indicating whether the firm is } \\
\text { wholly owned by a foreign individual or } \\
\text { foreign firm }\end{array}$ & BEEPS \\
\hline Institutional development & Score of the Economic Freedom Index & $\begin{array}{l}\text { Heritage Foundation } \\
\text { and Wall Street Journal }\end{array}$ \\
\hline EU & $\begin{array}{l}\text { Dummy indicating whether the firm is } \\
\text { situated in a EU-member country }\end{array}$ & European Union \\
\hline WI & $\begin{array}{l}\text { Dummy indicating whether the firm is } \\
\text { situated in a country with weak institutions } \\
\text { (Economic Freedom Index below median) }\end{array}$ & $\begin{array}{l}\text { Heritage Foundation } \\
\text { and Wall Street Journal }\end{array}$ \\
\hline
\end{tabular}

Table 3 contains the descriptive statistics, separated by EU-membership status. ${ }^{11} 55 \%$ of the firms developed a new product within the last three years in EU countries and 52\% in non-EU countries. With regard to the proportion of new product related sales we also see only slight differences in the average values of around $14 \%$ in both groups. The difference in the median values of $5 \%$ for firms situated in the EU and $2 \%$ for firms situated outside the

\footnotetext{
11 Descriptive statistics separated by the level of institutional development as measured by the Economic Freedom Index can be found in the appendix, Table A2.
} 
EU stems largely from a somewhat higher fraction of innovative firms with relatively low proportions of innovation related sales inside the EU.

Table 3 - Descriptive statistics

\begin{tabular}{lcccccc} 
& \multicolumn{7}{c}{ EU-member } \\
\cline { 2 - 7 } Variable & Obs. & Mean & Median & Std. Dev. & Min & Max \\
\hline New product/service & 2278 & 0.55 & 1 & 0.50 & 0 & 1 \\
Innovation sales & 2278 & 13.47 & 5 & 20.94 & 0 & 100 \\
R\&D dummy & 2278 & 0.26 & 0 & 0.44 & 0 & 1 \\
Experience & 2278 & 17.83 & 16 & 9.58 & 1 & 53 \\
Employees $_{\mathrm{t}-3}$ & 2278 & 87.29 & 22 & 370.30 & 1 & 15000 \\
Age $_{\mathrm{t}-3}$ & 2278 & 13.44 & 12 & 13.73 & 1 & 181 \\
Human capital $_{\text {Export }}$ t-3 & 2278 & 15.93 & 10 & 21.51 & 0 & 100 \\
State owned & 2278 & 0.31 & 0 & 0.46 & 0 & 1 \\
Foreign owned & 2278 & 0.02 & 0 & 0.13 & 0 & 1 \\
Institutional development & 2278 & 0.13 & 0 & 0.34 & 0 & 1 \\
\hline
\end{tabular}

non-EU-member

\begin{tabular}{lcccccc}
\cline { 2 - 7 } Variable & Obs. & Mean & Median & Std. Dev. & Min & Max \\
\hline New product/service & 5528 & 0.52 & 1 & 0.50 & 0 & 1 \\
Innovation sales & 5528 & 14.74 & 2 & 22.89 & 0 & 100 \\
R\&D dummy & 5528 & 0.24 & 0 & 0.43 & 0 & 1 \\
Experience & 5528 & 16.92 & 15 & 10.67 & 1 & 75 \\
Employees $_{\mathrm{t}-3}$ & 5528 & 100.90 & 24 & 362.40 & 1 & 15000 \\
Age $_{\mathrm{t}-3}$ & 5528 & 14.48 & 10 & 16.69 & 1 & 178 \\
Human capital $_{\text {Export }_{\mathrm{t}-3}}^{5528}$ & 27.65 & 20 & 26.37 & 0 & 100 \\
State owned $_{\text {Foreign owned }}^{5528}$ & 0.21 & 0 & 0.41 & 0 & 1 \\
Institutional development & 5528 & 0.05 & 0 & 0.21 & 0 & 1 \\
& 5528 & 0.08 & 0 & 0.26 & 0 & 1 \\
& 5528 & 56.47 & 56.60 & 6.02 & 45.30 & 69.90 \\
\hline
\end{tabular}

For our main variable of interested, managerial experience, we observe only slight average differences between EU and non-EU countries. This applies also to the median. Having a closer look at the distribution, however, reveals that in non-EU countries the proportion of firms led by relatively inexperienced top managers (i.e. 10 years and less) is much higher than in EU countries (see Figure 1). A similar pattern is also observed in Figure 1 for the sample split by weak vs. strong institutions as defined by the economic freedom rating. 
Referring to the control variables we observe some structural differences between EU and non-EU countries. Interestingly, non-EU firms are larger, on average (101 versus 87 employees in $t$-3) and have a higher fraction of employees with a university degree (28\% versus $16 \%) .{ }^{12}$ EU firms are more internationalized as they exported in 31 out of 100 cases on average, compared to $21 \%$ exporting firms in non-EU countries. Additionally, EU firms are less likely to be state-owned ( $2 \%$ versus $5 \%$ ), but more likely to be foreign owned (13\% versus $8 \%$ ). The average age of a firm amounts with 13 (non-EU) and 14 (EU) years to similar values in both samples.

Figure 1 - Sample distribution of managerial experience
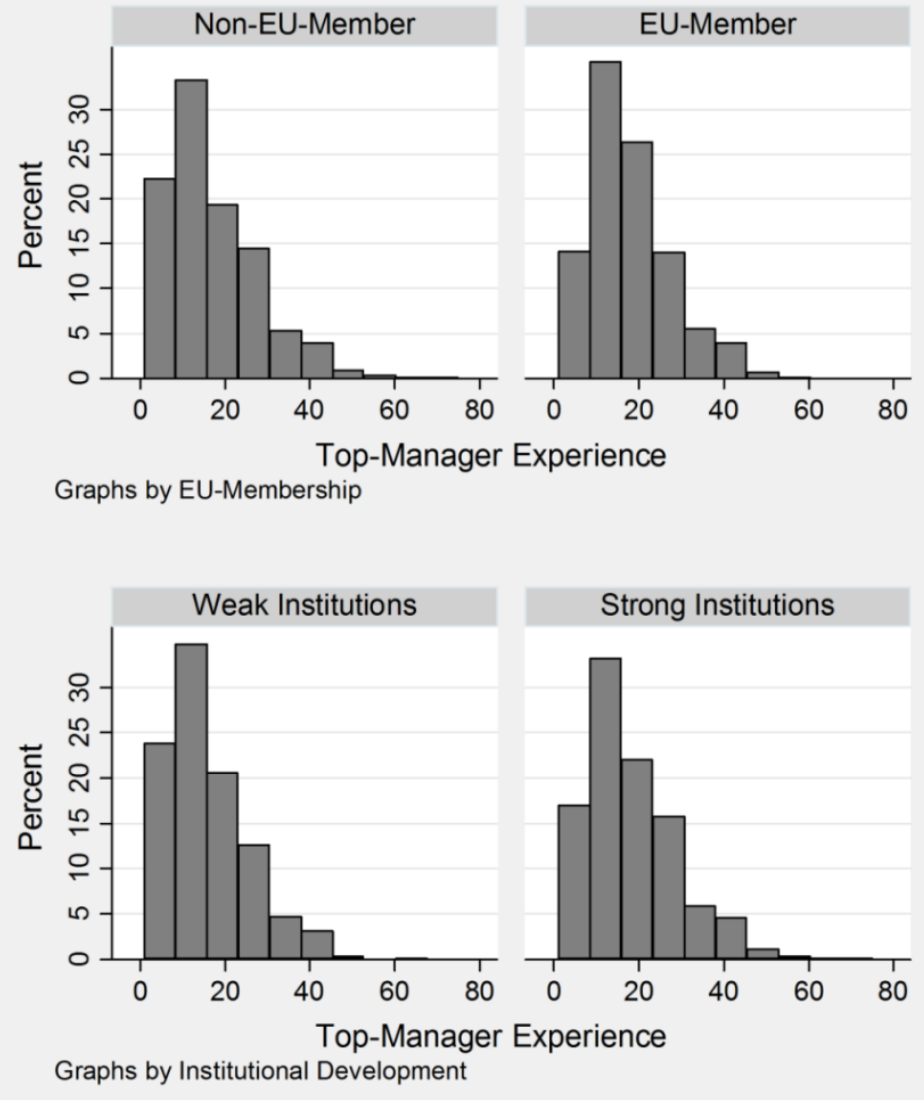

\footnotetext{
${ }^{12}$ It might seem puzzling that the employees in countries with weaker institutions have on average a higher formal education than those in countries with well-developed countries. This is however frequently observed and owes to the fact that in countries with weaker institutions the quality standards for education are lower. We ran the subsequent regressions also with the human capital variable adjusted by the average education level per country and the results did not change.
} 


\section{Empirical findings}

\subsection{Regressions using the full sample}

Since a firm's decision whether to innovate or not is indicated by a dichotomous variable, we use a Probit model to estimate the effect of experience on the probability to introduce a new product or service. For the proportion of sales accounted for by new products we use a Tobit model, which accounts for the censoring at zero occurring when firms did not introduce a new product or service. Both innovation proxies, new product or service introductions as well as sales from new products, are separately regressed on the logarithm of experience of the top-manager of each firm and all other above mentioned explanatory variables. ${ }^{13}$ This approach leaves us with two basic specifications, one for each dependent variable.

As heteroscedasticity in Probit and Tobit models would render coefficient estimates inconsistent, we conducted several tests. Finally, we specify the heteroscedasticity as groupwise multiplicatively where we allow the variance to vary across firm size, industries and countries. We use a full set of industry dummies and include three size dummies distinguishing four categories of firm sizes based on the quartiles of the employment distribution. In the Tobit models, we include a full set of country dummies. In the Probit models it turned out that it is sufficient to include three dummies of countries that show significantly different variance estimates from the other countries (see e.g. Verbeek, 2012, for technical details on estimating heteroscedastic Probit and Tobit models). ${ }^{14}$ Note further that

\footnotetext{
${ }^{13}$ We also tested other functional forms of experience but did not find other significant results. Specifications of a hump-shaped slope were sometimes significant but with turning points close to the maximum of observed values of experience which confirms our findings using the logarithm of experience.

${ }^{14}$ Note that, in the case of innovation sales, it would have been desirable to estimate Heckman-type selection models as more flexible version of the Tobit separating the decision to innovate and the success in terms of sales. However, in order to do so, we would require a convincing exclusion restriction, i.e. one variable that significantly determines the innovation decision that at the same time does not determine the sales of innovative products. As we do not have a good candidate for such a variable in our data, we restrict the analysis to Tobit models.
} 
all subsequently presented results are actually even more pronounced in terms of statistical significance when homoscedastic Probit and Tobit models are estimated.

First of all we are interested in the overall effect of managerial experience on innovative firm performance. Table 4 models $a$ and $b$ present the according results. Model $a$ shows a weak significant positive relation between managerial experience and the likelihood to introduce a new product or service but no significant effect on the sales stemming from newly introduced products.

To further investigate whether the effect of managerial experience on innovative firm performance changes across different institutional environments, we split the experience variable into two variables, one measuring managerial experience in firms operating inside the EU ('experience $x$ EU') and one variable measuring managerial experience in firms operating in non-EU-member states ('experience $x$ non-EU'). Both variables are mutually exclusive, meaning that they take zero values if firms operate in the excluded group of countries. This approach allows direct comparisons of the effects of managerial experience on innovative performance of firms operating inside in contrast to firms operating outside the EU. Similarly, as a kind of robustness check, we measure managerial experience in institutionally less developed countries ('experience $x$ WI') and countries with relative strong institutions ('experience $x S^{\prime}$ ') according to the economic freedom index of the Heritage Foundation. The regression results for the EU split are presented in columns $c$ and $d$, and the regression results for the latter split are presented in columns $e$ and $f$ of Table $4 .{ }^{15}$ Note that we do not include a non-EU dummy or respectively weak institutions dummy separately in the regressions as this variation is fully captured by the set of country dummies.

\footnotetext{
${ }^{15}$ Note that all results also hold if the models are estimated with the subsamples of EU and non-EU countries and respectively strong and weak institutions separately. In the tables we present here, we implicitly assume that the coefficients of the other controls do not differ across the different sub-samples. As making the estimations more flexible in this respect did not yield any different results concerning our main hypotheses, we opt for the space-saving presentation of just interacting managerial experience with the institutional variables here.
} 
Table 4 - Innovative firm performance

\begin{tabular}{|c|c|c|c|c|c|c|}
\hline \multirow[b]{2}{*}{ Dependent variable: } & \multicolumn{2}{|l|}{$\mathbf{a}$} & \multirow{2}{*}{$\begin{array}{c}\text { c } \\
\text { New product }\end{array}$} & \multirow{2}{*}{$\begin{array}{c}\text { d } \\
\text { Inno sales }\end{array}$} & e & \multirow{2}{*}{$\begin{array}{c}\text { 1 } \\
\text { Inno sales }\end{array}$} \\
\hline & New product & Inno sales & & & New product & \\
\hline R\&D dummy & $\begin{array}{c}0.963 * * * \\
(0.118)\end{array}$ & $\begin{array}{c}19.864 * * * \\
(1.024)\end{array}$ & $\begin{array}{c}0.957 * * * \\
(0.117)\end{array}$ & $\begin{array}{c}19.845 * * * \\
(1.024)\end{array}$ & $\begin{array}{c}0.971 * * * \\
(0.119)\end{array}$ & $\begin{array}{c}19.850 * * * \\
(1.024)\end{array}$ \\
\hline $\log \left(\right.$ employees $\left._{\mathrm{t}-3}\right)$ & $\begin{array}{c}0.030 * * \\
(0.013)\end{array}$ & $\begin{array}{l}0.605^{*} \\
(0.355)\end{array}$ & $\begin{array}{c}0.029 * * \\
(0.013)\end{array}$ & $\begin{array}{c}0.580 \\
(0.355)\end{array}$ & $\begin{array}{c}0.030 * * \\
(0.014)\end{array}$ & $\begin{array}{l}0.589 * \\
(0.355)\end{array}$ \\
\hline $\log \left(\operatorname{age}_{t-3}\right)$ & $\begin{array}{c}0.008 \\
(0.021)\end{array}$ & $\begin{array}{c}-1.768 * * * \\
(0.569)\end{array}$ & $\begin{array}{c}0.010 \\
(0.020)\end{array}$ & $\begin{array}{c}-1.734 * * * \\
(0.569)\end{array}$ & $\begin{array}{c}0.011 \\
(0.021)\end{array}$ & $\begin{array}{c}-1.715^{* * *} * \\
(0.570)\end{array}$ \\
\hline Human capital & $\begin{array}{c}0.002 * * * \\
(0.001)\end{array}$ & $\begin{array}{c}0.081 * * * \\
(0.020)\end{array}$ & $\begin{array}{c}0.002 * * * \\
(0.001)\end{array}$ & $\begin{array}{c}0.082 * * * \\
(0.020)\end{array}$ & $\begin{array}{c}0.002 * * * \\
(0.001)\end{array}$ & $\begin{array}{c}0.081 * * * \\
(0.020)\end{array}$ \\
\hline Export $_{\mathrm{t}-3}$ & $\begin{array}{c}0.281 * * * \\
(0.056)\end{array}$ & $\begin{array}{c}5.429 * * * \\
(1.137)\end{array}$ & $\begin{array}{c}0.280 * * * \\
(0.056)\end{array}$ & $\begin{array}{c}5.476^{* * * *} \\
(1.136)\end{array}$ & $\begin{array}{c}0.282 * * * \\
(0.057)\end{array}$ & $\begin{array}{c}5.400 * * * \\
(1.136)\end{array}$ \\
\hline State owned & $\begin{array}{l}-0.085 \\
(0.088)\end{array}$ & $\begin{array}{l}-4.279 * \\
(2.333)\end{array}$ & $\begin{array}{l}-0.083 \\
(0.088)\end{array}$ & $\begin{array}{l}-4.201 * \\
(2.337)\end{array}$ & $\begin{array}{l}-0.089 \\
(0.090)\end{array}$ & $\begin{array}{l}-4.300^{*} \\
(2.335)\end{array}$ \\
\hline Foreign owned & $\begin{array}{c}0.251 * * * \\
(0.064)\end{array}$ & $\begin{array}{c}5.189 * * * \\
(1.408)\end{array}$ & $\begin{array}{c}0.247 * * * \\
(0.064)\end{array}$ & $\begin{array}{c}5.084 * * * \\
(1.408)\end{array}$ & $\begin{array}{c}0.254 * * * \\
(0.065)\end{array}$ & $\begin{array}{c}5.141 * * * \\
(1.408)\end{array}$ \\
\hline $\log ($ experience $)$ & $\begin{array}{l}0.042 * \\
(0.024)\end{array}$ & $\begin{array}{c}0.934 \\
(0.635)\end{array}$ & & & & \\
\hline $\log ($ experience $) \times \mathrm{EU}$ & & & $\begin{array}{l}-0.069 \\
(0.046)\end{array}$ & $\begin{array}{l}-1.473 \\
(1.202)\end{array}$ & & \\
\hline $\log ($ experience $) \times$ non-EU & & & $\begin{array}{c}0.076^{* * * *} \\
(0.027)\end{array}$ & $\begin{array}{c}1.807 * * \\
(0.737)\end{array}$ & & \\
\hline $\log ($ experience $) \times$ SI & & & & & $\begin{array}{c}0.000 \\
(0.031)\end{array}$ & $\begin{array}{c}-0.121 \\
(0.898)\end{array}$ \\
\hline $\log ($ experience $) \times \mathrm{WI}$ & & & & & $\begin{array}{c}0.093 * * * \\
(0.036) \\
\end{array}$ & $\begin{array}{c}1.924 * * \\
(0.873) \\
\end{array}$ \\
\hline Joint significance of industry dummies $\chi^{2}(17)$ & $52.58 * * *$ & $122.35 * * *$ & $52.83 * * *$ & $121.64 * * *$ & $52.92 * * *$ & $122.16^{* * *}$ \\
\hline Joint significance of country dummies $\chi^{2}(25)$ & $61.05^{* * *}$ & $156.74 * * *$ & $59.69 * * *$ & $158.35 * * *$ & $57.40 * * *$ & $132.76^{* * *}$ \\
\hline No. of observations & 7806 & 7806 & 7806 & 7806 & 7806 & 7806 \\
\hline Pseudo R-squared & 0.139 & 0.031 & 0.140 & 0.031 & 0.139 & 0.031 \\
\hline Log-likelihood & -4648.22 & -22063.32 & -4644.24 & -22060.54 & -4646.09 & -22061.94 \\
\hline LR test for heteroscedasticity $\chi^{2}(44$ or 23$)$ & $52.08 * * *$ & $336.36 * * *$ & $53.91 * * *$ & $341.92 * * *$ & $53.50 * * *$ & $339.11 * * *$ \\
\hline
\end{tabular}


Table 4, models $c$ and $d$, reveal that managerial experience has a significant positive influence on the probability to introduce a new product $(c)$ as well as the proportion of new product sales $(d)$, for those firms operating outside the EU. For firms situated inside the EU the managerial experience coefficient turns insignificant in both models. Chi-squared tests on the difference between the experience coefficients for firms operating in the EU and outside the EU confirm that managerial experience has a statistically significant higher effect in the latter compared to the former region (one sided test, $p$-value $=0.004$ [Probit], $p$-value $=0.009$ [Tobit]).

With regard to the marginal effects this means, for instance, that the probability of introducing a new product by an average firm operating outside the EU rises by $13.7 \%$ if a non-experienced manager would be replaced by a manager that has 10 additional years of experience. ${ }^{16}$ The same exchange is associated with a $14.2 \%$ increase in the proportion of sales accounted for by new products, which indicates that firms with more experienced managers are not only more innovative but also more successful in commercializing their inventions.

Represented in the logarithmic specification, the marginal returns of managerial experience descend with increasing years of experience. Replacing a manager that has already 10 years of industry-specific experience by one who can look back on 20 years of experiences increases the probability to introduce a new product at a relatively low level of $3.9 \%$ (4.4\% when new product-related sales are considered). This is in line with the intuitive interpretation that the first years of industry-specific experiences are the most valuable. After ten years working in an industry managers have probably accumulated most of the knowledge that is needed, for instance, to deal effectively with governmental matters or how to write and enforce contracts when external institutions are weak. During the first decade

\footnotetext{
${ }^{16}$ Note that we calculate the relative change from the mean here rather than the change in percentage points. The corresponding change for the marginal effect of $13.7 \%$ as mentioned above would mean that the likelihood to innovate changes from $52 \%$ (sample mean) to about $59 \%$.
} 
working in an industry managers are most likely also able to build up reliable relationships with customers, suppliers and capable employees. Such a connectedness with key actors within an industry is probably most important to profitably innovate in less developed regions and may explain a large part of the positive relationship found between managerial experience and innovative firm performance.

As previously mentioned, we alternatively re-grouped firms according to the median level of institutional development, as measured by the economic freedom index of the Heritage Foundation. This allows us to complement and test the robustness of the results derived from the EU-split, which suggests that managerial experience is most valuable in less developed institutional surroundings. Models $e$ and $f$ of Table 5 show the corresponding regressions.

Again managerial experience of the top-manager is only significantly and positively related to the probability of introducing a new product $(e)$ and new product related sales $(f)$ for firms situated in weakly developed countries, while managerial experience has no significant influence on corporate innovative activity of firms situated in more developed regions (coefficients are again statistically different, one sided test, $p$-value $=0.023$ [Probit] $p$-value $=0.049$ [Tobit]). Compared with the results of models $c$ and $d$, the estimated coefficients of managerial experience in the sub sample of weakly developed countries are slightly higher than in the non EU-member subsample. More precisely, for an average firm operating in weakly developed environments an exchange of a non-experienced manager by a manager that has 10 additional years of industry-specific experience is associated with a $16.7 \%$ rise in the probability of introducing a new product or service, while the proportion of shares from newly introduced products would rise by $15.7 \%$. These results suggest that the only weakly significant positive (model $a$ ) and insignificant effect of managerial experience 
on innovative firm performance (model $b$ ) in the full-sample are driven by the group of firms operating in rather well developed institutional surroundings.

A reasoning consistent with these findings is that managerial experience substitutes for institutional shortfalls in ways like offering reputation, trustworthiness, and personal contacts to the government, customers and suppliers. It is known from the literature that institutional shortfalls like weak contract enforcement, political instability and uncertain prospects of future developments hamper firms' efforts to introduce new products and chances to commercialize innovations successfully. Hence, managerial reputation for contract fulfilling, for instance, becomes more important the weaker contracts are enforceable by court. Similar, experience in how to cope with governmental obstacles is most important in environments where governments are less predictable. Regardless of the exact channels through which managerial experience affects firms' decisions to innovate, they point all to the fact that experience of the top-manager reduces uncertainty on future returns on innovations, which is generally more valuable the less reliable the institutional environment.

\subsection{Small firms vs. large firms}

The empirical analysis points out that the top-manager of a firm has an important influence on the decision to innovate and the success of the commercialization of new products. This influence might be especially pronounced in small firms, where the success of the firm hinges more than in large firms on the knowledge, connectedness and reputation of one single person leading the firm. For suppliers, customers and employees of small firms the top-manager will often be the first person to negotiate with. Adding to this, crucial knowledge on how to commercialize new products and how to cope with governmental obstacles is often solely provided by the top-manager. Against this background, it is reasonable to expect that top-manager experience becomes more important for innovative firm performance of small firms compared to rather large ones. 
Small firms are further of particular interest as they constitute the far majority of firms in Central and Eastern European countries. Moreover are innovative small firms often considered as the fastest growing firms within an industry that have the highest impact on economic growth (e.g., among many others, Schneider \& Veugelers, 2010, Czarnitzki \& Delanote, 2013). Supplementing our previous analysis, we hence examine the influence of industry-specific experience of the top-manager on the probability to introduce new products as well as new product-related sales, separately for small and larger firms. We follow the European Commission in defining small firms as having less than 50 employees. All other firms are considered as one group of medium-sized and large firms. ${ }^{17}$ After separating these two groups of firms we run our baseline models of the decision to innovate and new product sales, as introduced in the previous subsection, separately for both groups. Since we know already that the experience effects vary significantly between institutionally more and less developed regions, we present only those models that allow to compare the experience effect for firms operating in the EU and outside the EU, and in better and less developed countries, respectively. This leaves us with 8 models, which are presented in table 6. Columns $a$ to $d$ show the results for small firms, while columns $e$ to $h$ comprise the results for medium-sized and large firms.

The regression results obtained for small firms are comparable to the full-sample results. Industry-specific experience of the top-manager has a significant positive effect on the probability that a small firm operating outside the EU introduces a new product (model $a$ ) and on the success in commercializing those new products (model $b$ ). The same applies for small firms operating in environments of low economic freedom (models $c$ and $d$ ). No significant effect of managerial experience on innovative firm performance is found for small

\footnotetext{
${ }^{17}$ In alternative specifications we also examined the influence of top-manager experience separately for medium sized firms (> 50 and up to 250 employees in $t-3$ ) and large firms (> 250 employees in $t-3$ ). Since the results did not change notably between medium-sized and large firms, we put both groups together in regressions presented here.
} 
firms operating in better developed institutional environments. From models $e$ to $f$ follows that, regardless of the institutional environment, experience seems to have no influence on innovative firm performance in medium-sized and large firms.

Looking at the size of the coefficients reveals that the experience effect stayed roughly the same for the decision to innovate for small firms compared to the effects revealed for the full sample of firms. The experience effect became larger, however, with regard to new product related sales of small firms, which is in line with the conjecture that the top-manager in general and managerial experience in particular is more important for small firms compared to large ones. Chi-squared tests on the difference between the experience coefficients of small versus medium and large firms in less developed countries actually confirm this perception statistically (one sided test; outside the EU: $p$-value $=0.004$ [Probit] $p$-value $=0.008$ [Tobit $] ;$ weak institutions: $p$-value $=0.005$ [Probit $], p$-value $=0.014$ [Tobit $]$ )

With regard to the marginal effects this means, for instance, that exchanging a topmanager of a small firm, operating outside the EU, with one year of industry-specific experience with a manager having 10 more years of experience is associated with a $14.5 \%$ (18.8\% in weak institutional environments) higher likelihood of new product introductions. The same exchange leads on average to a $24.7 \%$ (30.8\% in weak institutional environments) higher proportion of sales accounted for by new products. Both effects are, thus, not only statistically significant but also economically significant. Following the logarithmic specification, the marginal effects diminish with rising years of industry-specific experience. Ten additional years of industry-specific experience of a top-manager of a small firm, who has already ten years of experience, are associated with a relatively low increase in the probability to introduce a new product of $4.2 \%$ (5.3\% in weak institutional environments) and a $8.0 \%$ (10.1\% in weak institutional environments) increase in new product related sales. 
Table 5 - Small and large firms

Small firms ( $\leq 50$ employees $)$

larger firms (> 50 employees)

\begin{tabular}{|c|c|c|c|c|c|c|c|c|}
\hline & $\mathbf{a}$ & b & c & d & e & $\mathbf{f}$ & $\mathbf{g}$ & $\mathbf{h}$ \\
\hline Dependent variable: & New product & Inno sales & New product & Inno sales & New product & Inno sales & New product & Inno sales \\
\hline R\&D & $\begin{array}{c}0.752 * * * \\
(0.135)\end{array}$ & $\begin{array}{c}22.836 * * * \\
(1.352)\end{array}$ & $\begin{array}{c}0.760 * * * \\
(0.137)\end{array}$ & $\begin{array}{c}22.808 * * * \\
(1.351)\end{array}$ & $\begin{array}{c}1.300^{* * *} \\
(0.232)\end{array}$ & $\begin{array}{c}15.605 * * * \\
(1.462)\end{array}$ & $\begin{array}{c}1.308 * * * \\
(0.233)\end{array}$ & $\begin{array}{c}15.626 * * * \\
(1.462)\end{array}$ \\
\hline $\log \left(\right.$ employees $\left._{\mathrm{t}-3}\right)$ & $\begin{array}{c}0.048 * * \\
(0.021)\end{array}$ & $\begin{array}{c}1.665 * * \\
(0.727)\end{array}$ & $\begin{array}{c}0.049 * * \\
(0.021)\end{array}$ & $\begin{array}{c}1.635^{* *} \\
(0.726)\end{array}$ & $\begin{array}{l}-0.013 \\
(0.048)\end{array}$ & $\begin{array}{l}-0.264 \\
(0.845)\end{array}$ & $\begin{array}{l}-0.014 \\
(0.048)\end{array}$ & $\begin{array}{l}-0.239 \\
(0.844)\end{array}$ \\
\hline $\log \left(\operatorname{age}_{t-3}\right)$ & $\begin{array}{c}0.005 \\
(0.021)\end{array}$ & $\begin{array}{c}-2.117 * * * \\
(0.804)\end{array}$ & $\begin{array}{c}0.003 \\
(0.021)\end{array}$ & $\begin{array}{c}-2.124 * * * \\
(0.804)\end{array}$ & $\begin{array}{c}-0.008 \\
(0.043)\end{array}$ & $\begin{array}{l}-1.007 \\
(0.782)\end{array}$ & $\begin{array}{c}-0.008 \\
(0.043)\end{array}$ & $\begin{array}{l}-1.014 \\
(0.782)\end{array}$ \\
\hline Human capital & $\begin{array}{c}0.002 * * \\
(0.001)\end{array}$ & $\begin{array}{c}0.067 * * * \\
(0.023)\end{array}$ & $\begin{array}{c}0.002 * * \\
(0.001)\end{array}$ & $\begin{array}{c}0.066^{* * * *} \\
(0.023)\end{array}$ & $\begin{array}{c}0.006 * * * \\
(0.002)\end{array}$ & $\begin{array}{c}0.114 * * * \\
(0.037)\end{array}$ & $\begin{array}{c}0.006^{* * *} * \\
(0.002)\end{array}$ & $\begin{array}{c}0.113 * * * \\
(0.037)\end{array}$ \\
\hline Export $_{\mathrm{t}-3}$ & $\begin{array}{c}0.247 * * * \\
(0.062)\end{array}$ & $\begin{array}{c}6.916 * * * \\
(1.522)\end{array}$ & $\begin{array}{c}0.250 * * * \\
(0.063)\end{array}$ & $\begin{array}{c}6.808 * * * \\
(1.521)\end{array}$ & $\begin{array}{c}0.412 * * * \\
(0.118)\end{array}$ & $\begin{array}{c}4.644 * * * \\
(1.596)\end{array}$ & $\begin{array}{c}0.406^{* * *} \\
(0.118)\end{array}$ & $\begin{array}{c}4.616^{* * * *} \\
(1.595)\end{array}$ \\
\hline State owned & $\begin{array}{c}-0.086 \\
(0.118)\end{array}$ & $\begin{array}{c}-4.028 \\
(4.434)\end{array}$ & $\begin{array}{l}-0.095 \\
(0.119)\end{array}$ & $\begin{array}{l}-4.177 \\
(4.434)\end{array}$ & $\begin{array}{c}-0.020 \\
(0.150)\end{array}$ & $\begin{array}{c}-2.246 \\
(2.565)\end{array}$ & $\begin{array}{c}-0.022 \\
(0.152)\end{array}$ & $\begin{array}{c}-2.291 \\
(2.563)\end{array}$ \\
\hline Foreign owned & $\begin{array}{c}0.235 * * * \\
(0.076)\end{array}$ & $\begin{array}{c}6.587 * * * \\
(2.098)\end{array}$ & $\begin{array}{c}0.240 * * * \\
(0.077)\end{array}$ & $\begin{array}{c}6.633 * * * \\
(2.097)\end{array}$ & $\begin{array}{c}0.280 * * \\
(0.118)\end{array}$ & $\begin{array}{c}3.774 * * \\
(1.816)\end{array}$ & $\begin{array}{c}0.289 * * \\
(0.119)\end{array}$ & $\begin{array}{c}3.785 * * \\
(1.816)\end{array}$ \\
\hline $\log ($ experience $) \times \mathrm{EU}$ & $\begin{array}{c}-0.063 \\
(0.048)\end{array}$ & $\begin{array}{l}-1.389 \\
(1.626)\end{array}$ & & & $\begin{array}{c}-0.083 \\
(0.100)\end{array}$ & $\begin{array}{c}-1.600 \\
(1.694)\end{array}$ & & \\
\hline $\log ($ experience $) \times$ non-EU & $\begin{array}{c}0.077 * * \\
(0.031)\end{array}$ & $\begin{array}{c}3.315 * * * \\
(1.043)\end{array}$ & & & $\begin{array}{c}0.062 \\
(0.054)\end{array}$ & $\begin{array}{l}-0.059 \\
(0.989)\end{array}$ & & \\
\hline $\log ($ experience $) \times$ SI & & & $\begin{array}{c}0.005 \\
(0.031)\end{array}$ & $\begin{array}{c}0.420 \\
(1.190)\end{array}$ & & & $\begin{array}{c}0.005 \\
(0.070)\end{array}$ & $\begin{array}{c}-0.750 \\
(1.282)\end{array}$ \\
\hline $\log ($ experience $) \times$ WI & & & $\begin{array}{c}0.100 * * \\
(0.041)\end{array}$ & $\begin{array}{c}3.883 * * * \\
(1.291)\end{array}$ & & & $\begin{array}{c}0.051 \\
(0.066) \\
\end{array}$ & $\begin{array}{c}-0.203 \\
(1.145) \\
\end{array}$ \\
\hline Joint significance of industry dummies $\chi_{2}^{2}(17)$ & 22.91 & $83.71 * * *$ & 22.72 & $83.40 * * *$ & $29.46 * *$ & $70.52 * * *$ & $29.21 * *$ & $70.84 * * *$ \\
\hline Joint significance of country dummies $\chi^{2}(25)$ & 28.84 & $133.06 * * *$ & 29.34 & $116.86^{* * *}$ & 31.95 & $70.75 * * *$ & 29.72 & $62.35 * * *$ \\
\hline No. of observations & 5318 & 5318 & 5318 & 5318 & 2488 & 2488 & 2488 & 2488 \\
\hline Pseudo R-squared & 0.128 & 0.032 & 0.127 & 0.032 & 0.191 & 0.041 & 0.190 & 0.041 \\
\hline Log-likelihood & -3214.77 & -14565.14 & -3216.20 & -14566.20 & -1370.10 & -7386.00 & -1370.85 & -7386.27 \\
\hline LR test for heteroscedasticity $\chi^{2}(45,44,22$ or 21$)$ & $38.15 * *$ & $227.75 * * *$ & $37.06 * *$ & $225.64 * * *$ & $38.15 * *$ & $235.12 * * *$ & $38.04 * *$ & $234.59 * * *$ \\
\hline
\end{tabular}

Notes: Heteroscedastic Probit (a, c, e, g) and Tobit models (b, d, f, h); heteroscedasticity is modeled groupwise multiplicatively; heteroscedasticity term includes 2 (1 in medium/large firms'

sample) size dummies, 17 industry dummies and 25 ( 3 in Probit) country dummies. All models include an intercept which is omitted in the table. Standard errors are in parentheses. $* * *, * *$ and $*$ indicate a significance level of $1 \%, 5 \%$, and $10 \%$, respectively. Also note that the interaction variables EU, non-EU, SI and WI are not included as separate regressors as these effects are already captured by the full set of country dummies. 


\subsection{Potential endogeneity of managerial experience}

A potential caveat of our study might be that managerial experience cannot be considered as an exogenous variable which would imply an inconsistent estimation of its effect on innovative firm activity. More experienced managers might self-select to lead more innovative firms, or firms that are intending to enhance their innovative firm performance may try to hire more experienced managers. We address these concerns first by checking for potential endogeneity of managerial experience in our empirical models based on Rivers \& Vuong (1988) tests in case of the Probit models, and Smith \& Blundell (1986) tests in case of the Tobit models.

Both tests require at least one instrument for the potential endogenous variable in question. We use the average managerial experience at an aggregated 2-digit industry level by country and region as well as the average managerial experience at each company size quartile by industry and country as instruments. Both instruments characterize the environment in which the firm operates. The notion behind using industry level instruments is that a single firm is presumably not able to significantly influence an industry but may be influenced by the behavior of its peer group in the same industry (Jaffe, 1986).

In a first step we regress managerial experience on all explanatory variables and the instruments (industry-region averages and industry-firm size class averages per country), using standard OLS regressions. The results confirm that both instruments are relevant as they are individually significant at the $1 \%$ level. In a second step we include the predicted residuals of this model as an additional regressor in our Probit and Tobit models of innovative firm performance. The estimated coefficient for the residuals are the test statistics for the null hypotheses of exogeneity of managerial experience (Wooldridge, 2002, p. 474). Exogeneity is actually never rejected at a reasonable statistical significance level of $10 \%$ or lower ( $p$-values ranging between 0.465 and 0.955 ). 
We address Staiger \& Stock's (1997) concern that endogeneity tests might be misleading if the instruments are weak. Therefore, we further checked the partial correlation between the potential endogenous variable and the instruments. If the partial F-statistic for the instruments exceeds 10, Staiger \& Stock (1997) propose that the instruments in question are not weak. Within our regression framework we found F-values ranging between 158.07 and 598.10 suggesting that we do not face a weak instrument problem.

Finally, we tested with Amemiya-Lee-Newey (Lee, 1992, and Newey, 1987) overidentification tests for Probit and Tobit models whether the instruments used are valid, meaning they are uncorrelated with the error term of the innovation equations. Since the null hypothesis of no error term correlation is never rejected ( $p$-values ranging between 0.194 and 0.994) we conclude that both instruments are valid. Given these test results, the managerial experience effect estimated in our empirical investigation seems not to be biased by an endogenous relation with innovative firm performance.

\section{Considering only sole proprietorships}

As some readers may not find the instrumental variables used in the preceding test convincing, as for instance, one would prefer instrumental variables varying at the firm level, we offer another, conceptually different, robustness test. In this second attempt to address potential concerns regarding the exogeneity of managerial experience in our regression framework, we re-estimate our baseline models on the subsample of firms that are run under the legal form 'sole proprietorship' and have less than 50 employees. The notion behind this test is that within the sample of sole proprietorships at least two sources of endogeneity, namely self-selection of experienced managers to more innovative firms and corresponding recruiting practices, are most likely not taking place. The main reason for this assumption is that sole proprietorships include an unlimited liability of the owner of the firm. Under such circumstances it is rarely observed that firms separate ownership and control rights. Hence, 
the industry-specific experience of an owner-manager is not influenced by selection effects in the market of top-managers. In addition, we restrict the sample of sole proprietorships to firms that have at maximum 50 employees, as it is most likely that owners of such firms are not willing to give up control. Although we cannot surely rule out that a fully liable owner of a small sole proprietorship hires a person helping with managerial tasks, we believe that cases where the owner gives up control and is thus no longer identified as the "top manager" in the survey interviews is highly unlikely. ${ }^{18}$ The corresponding estimations are presented in Table 7. Note that we had to aggregate some industries because of the smaller samples and that three countries were excluded completely from this robustness tests because of small numbers of observations.

All regressions show qualitatively the same results as previously presented. The effect of managerial experience on new product introductions as well as new product related sales is always highly significant and positive for firms operating outside the EU and, more generally, in less developed institutional surroundings. Although not all possible estimation biases and alternative theoretical explanations can be ruled out by this approach, the results are reassuring in the sense that we should not be concerned of severely biased coefficients of managerial experience due to self-selection of experienced managers to more innovative firms.

\footnotetext{
${ }^{18}$ More experienced managers running their own business might be hired by other firms and, thus, select themselves out of the sample. This kind of self-selection, if it takes place, is of much less concern as it would imply an underestimation of the experience effect rather than an overestimation.
} 
Table 7 - Sole proprietorships

\begin{tabular}{|c|c|c|c|c|}
\hline \multirow[b]{2}{*}{ Dependent variable } & $\mathbf{a}$ & b & c & d \\
\hline & New product & Inno sales & New product & Inno sales \\
\hline $\mathrm{R} \& \mathrm{D}$ & $\begin{array}{c}0.959 * * * \\
(0.141)\end{array}$ & $\begin{array}{c}19.950 * * * \\
(3.513)\end{array}$ & $\begin{array}{c}0.949 * * * \\
(0.141)\end{array}$ & $\begin{array}{c}19.782 * * * \\
(3.532)\end{array}$ \\
\hline $\log \left(\right.$ employees $\left._{\mathrm{t}-3}\right)$ & $\begin{array}{c}0.018 \\
(0.054)\end{array}$ & $\begin{array}{c}0.373 \\
(1.635)\end{array}$ & $\begin{array}{c}0.023 \\
(0.054)\end{array}$ & $\begin{array}{c}0.346 \\
(1.629)\end{array}$ \\
\hline $\log \left(\operatorname{age}_{t-3}\right)$ & $\begin{array}{c}0.009 \\
(0.065)\end{array}$ & $\begin{array}{c}1.761 \\
(1.938)\end{array}$ & $\begin{array}{c}0.008 \\
(0.065)\end{array}$ & $\begin{array}{c}1.745 \\
(1.912)\end{array}$ \\
\hline Human capital & $\begin{array}{c}0.001 \\
(0.002)\end{array}$ & $\begin{array}{c}0.058 \\
(0.054)\end{array}$ & $\begin{array}{c}0.001 \\
(0.002)\end{array}$ & $\begin{array}{c}0.060 \\
(0.053)\end{array}$ \\
\hline Export $_{\mathrm{t}-3}$ & $\begin{array}{c}0.574 * * * \\
(0.163)\end{array}$ & $\begin{array}{c}14.645 * * * \\
(4.172)\end{array}$ & $\begin{array}{c}0.578 * * * \\
(0.164)\end{array}$ & $\begin{array}{c}14.801 * * * \\
(4.204)\end{array}$ \\
\hline Foreign owned & $\begin{array}{c}0.753 \\
(0.465)\end{array}$ & $\begin{array}{l}-1.319 \\
(9.551)\end{array}$ & $\begin{array}{c}0.747 \\
(0.461)\end{array}$ & $\begin{array}{l}-0.360 \\
(9.311)\end{array}$ \\
\hline $\log ($ experience $) \times \mathrm{EU}$ & $\begin{array}{c}-0.173 \\
(0.170)\end{array}$ & $\begin{array}{c}-8.729 * \\
(4.553)\end{array}$ & & \\
\hline $\log ($ experience $) \times$ non-EU & $\begin{array}{c}0.212^{* *} \\
(0.085)\end{array}$ & $\begin{array}{c}7.545^{* * * *} \\
(2.626)\end{array}$ & & \\
\hline $\log ($ experience $) \times$ SI & & & $\begin{array}{l}-0.095 \\
(0.124)\end{array}$ & $\begin{array}{l}-5.728^{*} \\
(3.473)\end{array}$ \\
\hline $\log ($ experience $) \times \mathrm{WI}$ & & & $\begin{array}{c}0.273 * * * \\
(0.095)\end{array}$ & $\begin{array}{c}9.013 * * * \\
(2.716) \\
\end{array}$ \\
\hline Joint significance of industry dummies $\chi^{2}(12)$ & $21.29 * *$ & 15.19 & $21.24 * *$ & 15.04 \\
\hline Joint significance of country dummies $\chi^{2}(22)$ & $74.59 * * *$ & $52.49 * * *$ & $69.25 * * *$ & $51.66 * * *$ \\
\hline No. of observations & 998 & 998 & 998 & 998 \\
\hline Pseudo R-squared & 0.144 & 0.049 & 0.145 & 0.049 \\
\hline Log-likelihood & -587.22 & -2455.57 & -586.40 & -2454.58 \\
\hline LR test for heteroscedasticity $\chi^{2}(37)$ & - & $66.46 * * *$ & - & $225.64 * * *$ \\
\hline
\end{tabular}

\section{Conclusion}

The present paper provides evidence of a positive influence of industry-specific experience of the top-manager on the likelihood that firms introduce new products as well as the proportion of new product related sales. Both effects are particularly pronounced for small firms operating outside the EU or, more general, in weak institutional environments. In contrast, firms that are situated in the EU or operate in more developed institutional environments seem not to profit from higher industry-specific experience of the top-manager, regardless of their size. 
We interpret these findings as support for the perception that managerial experience affects innovative firm performance largely indirectly, for instance, by superior knowledge on how to protect new inventions from being imitated, how to cope with governmental obstacles or how to commercialize new products. All these issues are presumably more essential for the decision to innovate and commercial success when external institutions are rather weak. Managerial experience thus substitutes for institutional shortfalls, like weak contract enforcement or political instability via reputation and knowledge on how to cope with institutional obstacles. While the BEEPS data do not allow disentangling the exact channels through which managerial experience affects a firm's decision to innovate, the present study has still important practical implications for policy makers, shareholders and investors. Since more experienced managers foster more innovative firm activities and thereby economic growth, countries with weak institutions may want to take experience of the top-manager into account when they decide, for instance, on subsidies for firms' $R \& D$ investments or foundations of new establishments. Shareholders that want to implement successful innovation strategies in institutionally weak environments should consider to do give leadership to the most experienced managers available. Similarly, potential investors that want to enter foreign markets may want to hire relatively experienced managers. Overall, our examination points out that building up industry-specific experiences might be a crucial factor to achieve sustainable firm growth and competitiveness, especially when external institutions a rather weak. 


\section{References}

Acemoglu, D., Johnson, S., \& Robinson, J.A. 2002. Reversal of Fortune: Geography and Institutions in the Making of the Modern World Income Distribution. Quarterly Journal of Economics, 118: 1231-1294.

Acemoglu, D., Johnson, S., \& Robinson, J.A. 2005. Institutions as the Fundamental Cause of Long-run Economic Growth. In: Aghion, P., Durlauf, S. (Eds.), Handbook of Economic Growth, North Holland.

Acs, Z.J., \& Audretsch, D.B. 1987. Innovation, Market Structure, and Firm Size. Review of Economics and Statistics, 69(4): 567-574.

Acs, Z.J., \& Audretsch, D.B. 1988. Innovation in Large and Small Firms: An Empirical Analysis, American Economic Review, 78(4): 678-690.

Acs, Z.J., Audretsch, D.B., \& Feldman, M.P. 1994. R\&D Spillovers and Recipient Firm Size. Review of Economics and Statistics, 76(2): 336-340.

Agarwal, R., Echambadi, R., Franco, A.M., \& Sarkar, M.B. 2004. Knowledge Transfer through Inheritance: Spin-out Generation, Development and Survival. Academy of Management Journal, 47: 500-521.

Arthur, W.B. 1994. Increasing Returns and Path Dependence in the Economy. Ann Arbor, MI: University of Michigan Press.

Bach, S.B., \& Smith, A.D. 2007. Are Powerful CEOs Beneficial to Post-IPO Survival in High Technology Industries? An Empirical Investigation. Journal of High Technology Management Research, 18: 31-42.

Barker, V.L., \& Mueller, G.C. 2002. CEO Characteristics and Firm R\&D Spending. Management Science, 48: 782-801. 
Eggers, J.P. \& Kaplan, S. 2009. Cognition and Renewal: Comparing CEO and Organizational Effects on Incumbent Adaptation to Technical Change. Organization Science, 20: $461-79$.

Barro, R. 1990. Economic Growth in a Cross Section of Countries. Quarterly Journal of Economics, 106: 407-433.

Baysinger, B.D., \& Hoskisson, R.E. 1989. Diversification Strategy and R\&D Intensity in Multiproduct Firms. Academy of Management Journal, 32: 310-332.

Baysinger, B.D., Kosnik, R.D., \& Turk, T.A. 1991. Effects of Board and Ownership Structure on Corporate R\&D Strategy. Academy of Management Journal, 34: 205214.

Beck, T., Demirguc-Kunt, A., \& Maksimovic, V. 2005. Financial and Legal Constraints to Firm Growth: Does Size Matter? Journal of Finance, 60: 137-177.

Belke, A., Bordon, I., Melnykovska, I., \& Schweickert, R. 2009. Prospective NATO or EU Membership and Institutional Change in Transition Countries. IZA Discussion Papers 4483, Institute for the Study of Labor (IZA).

Bertrand, M., \& Schoar, A. 2003. Managing with Style: The Effect of Managers on Firm Policies. Quarterly Journal of Economics, 118: 1169-208.

Bertschek, I., \& Entorf, H. 1996. On Nonparametric Estimation of the Schumpeterian Link between Innovation and Firm Size. Empirical Economics, 21(3): 401-426.

Branstetter, L.G., Fisman, R., \& Foley, C.F. 2006. Do Stronger Intellectual Property Rights Increase International Technology Transfer? Empirical Evidence from U.S. FirmLevel Panel Data. Quarterly Journal of Economics, 121: 321-349.

Chetty, S., Eriksson, K., \& Lindbergh, J. 2006. The Effect of Specificity of Experience on a Firm's Perceived Importance of Institutional Knowledge in an Ongoing Business. Journal of International Business Studies, 37: 699-712. 
Claessens, S., \& Laeven, L., 2003. Financial Development, Property Rights, and Growth. Journal of Finance, 58: 2401-2435.

Czarnitzki, D., \& Delanote, J. 2013, Young Innovative Companies: the new high-growth firms? Industrial and Corporate Change, 22(5): 1315-1340.

Czarnitzki, D., \& Kraft, K. 2009. Capital Control, Debt Financing and Innovative Activity. Journal of Economic Behavior \& Organization, 71: 372-383.

Czarnitzki, D., \& Toole, A.A. 2011. Patent Protection, Market Uncertainty, and R\&D Investment. Review of Economics and Statistics, 93(1): 147-159.

Czarnitzki, D., \& Toole, A.A. 2013. The R\&D Investment-Uncertainty Relationship: Do Strategic Rivalry and Firm Size Matter? Managerial and Decision Economics 34(1): $15-28$.

Dahl, M., \& Reichstein, T. 2007. Are You Experienced? Prior Experience and the Survival of New Organizations. Industry \& Innovation, 14: 497-511.

Djankov, S., La Porta, R., Lopez-De-Silanes, F., \& Shleifer, A. 2003. Courts. Quarterly Journal of Economics, 119: 453-517.

Filatotchev, I., Jackson, G., \& Nakajima, C. 2012. Corporate Governance and National Institutions: A Review and Emerging Research Agenda. Asia Pacific Journal of Management: forthcoming. doi: 10.1007/s10490-012-9293-9.

Filatochev, I., Liu, X., Buck, T., \& Wright, M. 2009. The Export Orientation and Export Performance of High-technology SMEs in Emerging Markets: The Effects of Knowledge Transfer by Returnee Entrepreneurs. Journal of International Business Studies, 40: 1005-1021.

Galasso, A., \& Simcoe, T. 2011. CEO Overconfidence and Innovation. Management Science, 57: 1469-1484. 
Garvin, D.A. 1983. Spin-offs and the New Firm Formation Process. California Management Review, 15: 3-20.

Glass, A.J., \& Saggi, K. 2002. Intellectual Property Rights and the Foreign Direct Investment. Journal of International Economics, 56: 387-410.

Griliches, Z. 1980. R\&D and the Productivity Slowdown. American Economic Review, 70: 343-348.

Griliches, Z., \& Mairesse J. 1984. Productivity and R\&D at the Firm Level. In: Z. Griliches (Ed.), R\&D, Patents, and Productivity. Chicago: University of Chicago Press.

Griliches, Z., \& Mairesse J. 1990. R\&D and Productivity Growth: Comparing Japanese and U.S. Manufacturing Firms. In: C. Hulten (Ed.), Productivity Growth in Japan and the United States. Chicago: University of Chicago Press.

Hall, B.H., \& Mairesse, J. 1995. Exploring the Relationship between R\&D and Productivity in French Manufacturing Firms. Journal of Econometrics, 65: 263-293.

Hall, B.H., Mairesse, J., \& Mohnen, P. 2010. Measuring the Returns to R\&D, in: B.H. Hall and N. Rosenberg (eds.), Handbooks in Economics: Economics of Innovation, Amsterdam: North-Holland: 1033-1082.

Helfat, C.E., \& Lieberman, M.B. 2002. The Birth of Capabilities: Market Entry and the Importance of Pre-history. Industrial and Corporate Change, 11: 725-760.

Helpman, E. 1993. Innovation, Imitation, and Intellectual Property Rights. Econometrica, 61: $1247-1280$.

Holmes, J.T., \& Schmitz, Jr., J.A. 1996. Managerial Tenure, Business Age, and Small Business Turnover. Journal of Labor Economics, 14: 79-99.

Hoskisson, R.E., Eden, L., Lau, C.M. \& Wright, M. 2000. Strategy in Emerging Economies. Academy of Management Journal, 43: 249-67. 
Hoskisson, R.E., Wright, M., Filatochev, I. \& Peng, M.W. 2012. Emerging Multinationals from Mid-Range Economies: The Influence of Institutions and Factor Markets. Journal of Management Studies: forthcoming. doi: 10.1111/j.14676486.2012.01085.x.

Jaffe, A.B. 1986. Technological Opportunity and Spillovers of R\&D: Evidence from Firms' Patents, Profits, and Market Value. American Economic Review, 76: 984-1001.

Johanson, J., \& Wiedersheim-Paul, F. 1975. The Internationalization Process of the Firm: Four Swedish Cases. Journal of Management Studies, 12: 305-322.

Johnson, S., \& McMillan, J., Woodruff, C. 2002. Property Rights and Finance. American Economic Review, 92: 1335-1356.

Khanna, T., \& Palepu, K. 1997. Why Focused Strategies May be Wrong for Emerging Markets. Harvard Business Review, 75: 41-51.

Kleinknecht, A. 1996. New Indicators and Determinants of Innovation: An Introduction. In: Kleinknecht, A. (Ed.), Determinants of Innovation: The Message from New Indicators. Macmillian Press Ltd., London, 1-12.

Klepper, S. 2001. Employee Start-ups in High-tech Industries. Industrial and Corporate Change, 10: 639-674.

Klepper, S., \& Simons, K.L. 2000. Dominance by Birthright: Entry of Prior Radio Producers and Competitive Ramifications in the US Television Receiver Industry. Strategic Management Journal, 21: 997-1016.

Kor, Y.Y., 2003. Experience-based Top Management Team Competence and Sustained Growth. Organization Science, 14: 707-719.

Kor, Y.Y., \& Misangyi, V.F. 2008. Outside Directors' Industry-Specific Experience and Firms’ Liability of Newness. Strategic Management Journal, 29: 1345-1355. 
Kor, Y.Y., \& Sundaramurthy, C. 2009. Experience-Based Human Capital and Social Capital of Outside Directors. Journal of Management, 35: 981-1006.

La Porta, R., Lopez-de-Silanes F., Shleifer A., \& Vishny, R. 1997. Legal Determinants of External Finance. Journal of Finance, 52: 1131-50.

La Porta, R., López de Silanes, F., Shleifer, A., \& Vishny, R. 1998. Law and finance. Journal of Political Economy, 106: 1113-1155.

La Porta, R., Lopez-de-Silanes F., Shleifer A., \& Vishny, R. 1999. The Quality of Government. Journal of Law, Economics and Organization, 15: 222-279.

La Porta, R., López de Silanes, F., Shleifer, A., \& Vishny, R. 2002. Investor Protection and Corporate Valuation. Journal of Finance, 62: 1147-1170.

La Porta, R., Lopez-de-Silanes F., \& Shleifer A. 2008. The Economic Consequences of Legal Origins. Journal of Economic Literature, 46: 285-332.

Lee, L. 1992. Amemiya's Generalized Least Squares and Tests of Overidenfication in Simultaneous Equation Models with Qualitative or Limited Dependent Variables. Econometric Reviews, 11: 319-328.

Li, H \& Zhang, Y. 2007. The Role of Managers' Political Networking and Functional Experience in New Venture Performance: Evidence from China's Transition Economy. Strategic Management Journal, 28: 791-804.

Lin, C., Lin, P., \& Song, F. 2010. Property Rights Protection and Corporate R\&D: Evidence from China. Journal of Development Economics, 93: 49-62.

Mackey, A. 2008. The Effect of CEOs on Firm Performance. Strategic Management Journal, 29: 1357-1367.

Meyer, K.E. \& Peng, M.W. 2005. Probing Theoretically into Central and Eastern Europe: Transactions, Resources, and Institutions. Journal of International Business Studies, 36: 600-21. 
Newey, W.K. 1987. Efficient Estimation of Limited Dependent Variable Models with Endogeneous Explanatory Variables. Journal of Econometrics, 36: 231-250.

North, D. 1990. Institutions, Institutional Change and Economic Performance. Cambridge University Press, Cambridge.

Peng, M.W. 2003. Institutional Transitions and Strategic Choices. Academy of Management Review, 28: 275-96.

Peng, M.W. \& Heath, P.S. 1996. The Growth of the Firm in Planned Economies in Transition: Institutions, Organizations, and Strategic Choice. Academy of Management Review, 21: 492-528.

Peng, M.W. \& Luo, Y. 2000. Managerial Ties and Firm Performance in a Transition Economy: The Nature of a Micro-Macro Link. Academy of Management Journal, 43: 486-501.

Pennings, J.M., Lee, K., \& Van Witteloostuijn, A. 1998. Human capital, Social Capital and Firm Dissolution. Academy of Management Journal, 41: 425-440.

Penrose, E.T. 1959. The Theory of the Growth of the Firm, Basil Blackwell: Oxford.

Rivers, D. \& Vuong, Q.H. 1988. Limited Information Estimators and Exogeneity Tests for Simultaneous Probit Models. Journal of Econometrics, 39: 347-366.

Romer, P.M. 1990. Endogenous Technical Change. Journal of Political Economy, 98: 71102.

Schankerman, M. 1981. The Effects of Double-Counting and Expensing on the Measured Returns to R\&D. Review of Economics and Statistics, 63: 454-458.

Scherer, F.M. 1984. Innovation and Growth: Schumpetarian Perspectives. MIT Press, Cambridge, MA. 
Schneider, C., \& Veugelers, R. 2010. On Young Highly Innovative Companies: Why They Matter and How (not) to Policy Support Them, Industrial and Corporate Change, 19: $1-39$.

Shane, S. 2000. Prior Knowledge and the Discovery of Entrepreneurial Opportunities. Organization Science, 11: 448-469.

Smith, R.J., \& Blundell, R.W. 1986. An Exogeneity Test for a Simultaneous Equation Tobit Model with an Application to Labor Supply. Econometrica, 54: 679-685.

Sorenson, O. 2003. Social Network and Industrial Geography. Journal of Evolutionary Economics, 13: 513-527.

Staiger, D., \& Stock, J.H. 1997. Instrumental Variables Regression with Weak Instruments. Econometrica, 65: 557-586.

Stiglitz, J. 1969. Theory of Innovation - Discussion. American Economic Review, 59: 4446.

Stuart, T.E., \& Sorenson, O. 2003. The Geography of Opportunity: Spatial Heterogeneity in Founding Rates and the Performance of Biotechnology Firms. Research Policy, 32: $229-253$.

Varselekis, N.C. 2001. The Impact of Patent Protection, Economy Openness and National Culture on R\&D Investment: A Cross-country Empirical Investigation. Research Policy, 30: 1059-1068.

Verbeek, M. 2012. A guide to Modern Econometrics, $4^{\text {th }}$ ed., Chichester: John Wiley \& Sons.

Weterings, A., \& Koster, S. 2007. Inheriting Knowledge and Sustaining Relationships: What Stimulates the Innovative Performance of Small Software Firms in the Netherlands? Research Policy, 36: 320-335. 
Wooldridge, J.M. 2002. Econometric Analysis of Cross Section and Panel Data. Cambridge, MA.

Wright, M., Filatotchev, I., Hoskisson, R.E. \& Peng, M.W. 2005. Strategy Research in Emerging Economies: Challenging the Conventional Wisdom. Journal of Management Studies, 42: 1-33. 


\section{Appendix}

Table A1 - Correlation matrix

\begin{tabular}{|c|c|c|c|c|c|c|c|c|c|c|c|c|}
\hline & $\begin{array}{l}\text { New } \\
\text { product } \\
\text { /service }\end{array}$ & Inno sales & $\begin{array}{l}\text { R\&D, } \\
\text { dummy }\end{array}$ & Experience & $\begin{array}{c}\text { Employees } \\
t-3\end{array}$ & $\operatorname{Age}_{t-3}$ & $\begin{array}{l}\text { Human } \\
\text { capital }\end{array}$ & Export $_{\mathrm{t}-3}$ & State owned & $\begin{array}{c}\text { Foreign } \\
\text { owned }\end{array}$ & EU & $\begin{array}{l}\text { Institutional } \\
\text { development }\end{array}$ \\
\hline New product/service & 1.000 & & & & & & & & & & & \\
\hline Inno sales & 0.608 & 1.000 & & & & & & & & & & \\
\hline R\&D, dummy & 0.317 & 0.226 & 1.000 & & & & & & & & & \\
\hline Experience & 0.003 & 0.004 & 0.059 & 1.000 & & & & & & & & \\
\hline Employees $_{\mathrm{t}-3}$ & 0.046 & 0.004 & 0.087 & 0.028 & 1.000 & & & & & & & \\
\hline $\operatorname{Age}_{t-3}$ & 0.031 & -0.023 & 0.088 & 0.185 & 0.188 & 1.000 & & & & & & \\
\hline Human capital & 0.059 & 0.060 & 0.039 & -0.094 & -0.018 & -0.086 & 1.000 & & & & & \\
\hline Export $_{\mathrm{t}-3}$ & 0.157 & 0.102 & 0.224 & 0.085 & 0.127 & 0.125 & -0.074 & 1.000 & & & & \\
\hline State owned & -0.014 & -0.039 & 0.020 & -0.026 & 0.133 & 0.194 & -0.013 & 0.010 & 1.000 & & & \\
\hline Foreign owned & 0.075 & 0.042 & 0.050 & -0.061 & 0.085 & -0.002 & 0.036 & 0.179 & 0.039 & 1.000 & & \\
\hline EU & 0.026 & -0.026 & 0.018 & 0.040 & -0.017 & -0.030 & -0.208 & 0.102 & -0.071 & 0.089 & 1.000 & \\
\hline Institutional development & -0.031 & -0.042 & -0.011 & 0.054 & -0.054 & -0.096 & -0.102 & 0.090 & -0.114 & 0.069 & 0.628 & 1.000 \\
\hline
\end{tabular}


Table A2 - Descriptive statistics

Strong institutions

\begin{tabular}{lcccccc}
\cline { 2 - 7 } Variable & Obs. & Mean & Median & Std. Dev. & Min & Max \\
\hline New product/service & 4447 & 0.51 & 1 & 0.50 & 0 & 1 \\
Innovation sales & 4447 & 13.60 & 1 & 22.06 & 0 & 100 \\
R\&D dummy & 4447 & 0.24 & 0 & 0.43 & 0 & 1 \\
Experience & 4447 & 18.21 & 15 & 10.70 & 1 & 75 \\
Employees $_{\text {t-3 }}$ & 4447 & 84.45 & 22 & 306.70 & 1 & 15000 \\
Age $_{\text {t-3 }}$ & 4447 & 12.84 & 11 & 12.59 & 1 & 181 \\
Human capital $_{\text {Export }}$ & 4447 & 21.79 & 10 & 25.79 & 0 & 100 \\
State owned $_{\text {Foreign owned }}^{4447}$ & 0.29 & 0 & 0.45 & 0 & 1 \\
Institutional development & 4447 & 0.02 & 0 & 0.14 & 0 & 1 \\
\hline
\end{tabular}

Weak institutions

\begin{tabular}{lcccccc}
\cline { 2 - 7 } Variable & Obs. & Mean & Median & Std. Dev. & Min & Max \\
\hline New product/service & 3359 & 0.55 & 1 & 0.50 & 0 & 1 \\
Innovation sales & 3359 & 15.39 & 5 & 22.68 & 0 & 100 \\
R\&D dummy & 3359 & 0.25 & 0 & 0.43 & 0 & 1 \\
Experience & 3359 & 15.83 & 14 & 9.76 & 1 & 66 \\
Employees $_{\text {t-3 }}$ & 3359 & 113.50 & 25 & 429.10 & 1 & 15000 \\
Age $_{\text {t-3 }}$ & 3359 & 15.95 & 10 & 19.27 & 1 & 178 \\
Human capital $_{\text {Export }_{\text {t-3 }}}^{3359}$ & 27.46 & 20 & 25.01 & 0 & 100 \\
State owned $_{\text {Foreign owned }}^{3359}$ & 0.18 & 0 & 0.39 & 0 & 1 \\
Institutional development & 3359 & 0.07 & 0 & 0.25 & 0 & 1 \\
\hline
\end{tabular}

